Sturcz Zoltán

Budapesti Müszaki és Gazdaságtudományi Egyetem

sturcz.z@eik.bme.hu

\title{
SZAKMAI ANYANYELV, SZAKKÉPZÉS A KÖZOKTATÁSBAN, NYELVPEDAGÓGIAI ÖSSZEFÜGGÉSEK
}

„A nyelv az egyének és társadalmak életében fontosabb szerepet játszik, mint bármi más."

Ferdinand de Saussure

\section{A szakmai tanárképzés területei és anyanyelvi, szaknyelvi feladatai}

A közoktatásra vonatkozó tanárképzés két nagy képzési területet fog át. Az egyik a közismereti tanárképzés, a másik az a sajátos képzési terület, amit a szakmai tanárképzés címszó alatt sorolnak fel. Ez utóbbinak a tanárképzésre vonatkozó rendeletek szerint hat ága van. Ez a hat ág a következő képzési, illetve szakmai területeket foglalja magába: agrár-, közgazdasági, műszaki, egészségügyi, gyógypedagógiai és pedagógiai tanárképzés. Ez az utóbbi kettő bizonyos értelemben kilóg a sorból, mivel több szempontból távol áll az felsorolásban szereplő előző négy területtől. A tanári képzéseket a szakegyetemek, illetve azok illetékes karainak keretében - a felsőoktatási törvénynek megfelelően - az ún. tanárképző központok koordinálják. A Budapesti Műszaki és Gazdaságtudományi Egyetem Tanárképző Központja a fenti szakmai képzések közül két területet gondoz: közgazdásztanár-képzés (öt szakiránnyal) és műszaki tanárképzés (tíz szakiránnyal), gyakorlatilag ezzel lefedve az összes szakirányt, illetve a teljes képzési kínálatot. A Mủegyetem ezeken a területeken jelentős tapasztalatokkal és nagy hagyományokkal rendelkezik. A hagyományokra hivatkozva meg kell említeni, hogy Eötvös József kultuszminiszter 1870-ben a Műegyetemen alapította és nyitotta meg az első hazai tanárképző intézményt, a reáltanári képezdét. A tapasztalatok és a hagyományok kapcsán pedig arról is szólni kell, hogy a Tanárképző Központ, illetve a Műszaki Pedagógia Tanszék - eltérő neveken és szervezeti keretekben - ez idő óta folyamatosan képez szakmai tanárokat a mindenkori magyar közoktatás, szakoktatás, szakképzés, felnőttképzés számára. A közelmúlt létszámadatai szerint ezek a képzések Tanárképző Központunkban 100-150 fö közötti mesterszintű évfolyamlétszámokkal működnek. Ide tartozik az az információ is, hogy a mesterszintủ szakmai tanárképzés mellett alapszakon műszaki szakoktatóképzést is végez az intézmény. A számok,

1 A mottóul választott idézet eredeti forrása: Saussure, Ferdinand de 1916/1983. Course in General Linguistics (szerk.: Charles Bally és Albert Sechehaye, fordította R. Harris). Duckworth: London. 21. 
a tapasztalatok és a felmérések birtokában vállalkozunk arra, hogy szakmai tanárképzés, illetve a közoktatás szakmai anyanyelvi kérdéseiről nyilatkozzunk.

A 2018/19-es tanév első félévében 105 fö - többnyire már oktatási gyakorlattal és tapasztalattal rendelkező - első évfolyamos műegyetemi mérnöktanár és közgazdásztanár hallgató, illetve oktató szakmai kommunikációs és szaknyelvi problémákat feltáró dolgozatát elemeztem. Hallgatóink - akik egyben szakmai tanárkollégáink is - A szakmai kommunikáció címü tantárgy keretében véleményüket, észrevételeiket mintegy háromoldalas általános és konkrét felvetéseket is tartalmazó, esszéjellegű fogalmazásban fejthették ki. A véleményeikből, példáikból, tapasztalataikból jelen tanulmányban idézek, a szó szerinti idézés esetén szögletes zárójelben jelöltem a felmérésben szereplő sorszámát. Az aktuális és konkrét felmérés anyagához hozzá kell tenni azt, hogy a több évtizedre kiterjedő korábbi ez irányú oktatási, képzési tapasztalatainkat is bevontam az itt bemutatott gondolati összegzésbe.

A tanárképzésre vonatkozó legújabb képzési és kimeneti követelmények egyértelműen elöírják, hogy anyanyelvi és kommunikációs tantárgyak szerepeljenek a szakmai tanárképzési tantervekben. A szakmai tanárképzés dokumentumai kiemelten foglalkoznak a szaknyelv, a szakmai kommunikáció előtérbe helyezésével, módszertani megjelenítésével (Berki 2015a, 2015b).

A Mủegyetemen ennek megfelelően született meg $A$ szakmai nyelvmüvelés alapjai, a Szakmai kommunikáció és részben a Prezentáció címü tantárgyunk. Ezek a tantárgyak a mindenkori szakmai tanárképzési program részeként is szerepelnek, sőt a teljes műegyetemi hallgatóság számára is nyitottak. Ezek esetében folyamatos átdolgozásról, modernizálásról beszélhetünk (Sturcz 2006, 2009, 2010). A hagyományok - az anyanyelvi képzésre vonatkoztatva - is élnek, illetve tovább élnek. Elég csak arra utalnom, hogy a két világháború között a teljes hallgató közönség számára nyitott volt a Magyar nyelvhelyesség és stílus I. és II. elnevezésü tantárgy. A kurzusokat Dengl János vezette, aki a tantárgyhoz Magyar nyelvhelyesség és magyar stílus címmel 468 oldalas tankönyvet is írt (Dengl 1937; Sturcz 2004). Sőt korábbra visszanyúlva azt is illik itt megemlíteni, hogy Szily Kálmán A magyar nyelvuijitás szótára két kötetének (I. 1902, II. 1908) a megalkotója, a Magyar Nyelvtudományi Társaság megalapítója és a Magyar Nyelv című folyóirat egyik szerkesztője, a Műegyetem polihisztor professzora, rektora volt. Szily Kálmán a szaknyelv kérdéseivel is foglalkozott. Már 1879-ben közreadta $A$ természettudományos münyelvröl címmel megírt nagy tanulmányát. Egyébként megemlítendő, hogy nyelvészeti tevékenységéért 1913-ban elnyerte az MTA Nagydiját (Grétsy 2002).

A szakmai tanárképzésben, majd a szakoktatás különféle területein tanító szakmai tanárok feladata igazából kettős feladat, kettős felelősség: egyrészt ki kell alakítani a tanulókban egy szakmai tudásközösséget, másrészt ezzel párhuzamosan ki kell alakítani egy szaknyelvi diskurzusközösséget is. A szakmai anyanyelv bemutatása, feltárása, készségszintű megtanítása a szakmai tanári munka során - a szaktantárgyak keretében - valósul meg (HrubosPfister szerk. 2011). 
A középfokú oktatási intézményekben szakterületen, szakképzésben - szakiskolában, szakmunkásképzőben, szakgimnáziumban (korábbi nevén szakközépiskolában) az összes középiskolás tanuló 56,9 \%-a, 243500 fö vesz részt a Központi Statisztikai Hivatal 2017/18-as tanévre szóló kimutatása szerint. Ehhez még szintén a hivatal adatai alapján hozzátehetjük azt a 90000 föt, akik a felnőttoktatás és egyben szakképzés keretében képzik magukat. (A felnőttoktatás - a továbbképzések, az átképzések, az utóképzések miatt - tendenciájában folyamatosan bővülö tanulói kört képez.) Ez a halmaz tehát összesítve mintegy 300-350 ezer före tehető. Tehát ennyi tanuló részesül a szakmai tudásközösség és a szaknyelvi diskurzusközösség kialakításának élményében. Ez a halmaz a nyolc közoktatási szakképzési terület tanulói halmaza, ami a következő szakképzési területeket foglalja magába: 1) műszaki tudományok, 2) gazdaság és irányítás, 3) informatika, 4) egészségügy, szociális ellátás, 5) szolgáltatás, 6) mezőgazdaság, 7) művészetek, 8) tanárképzés, oktatástudomány. Ebből az általunk vizsgált közgazdasági és műszaki képzés - beleértve az informatikai területet is - adja a túlnyomó részt, körülbelül az összes szakképzés 75\%-át - amint ez a KSH képzési területeket bemutató és részletező 5. számú ábrájából kiderül (Statisztikai Tükör 2018: 1-3). Ez az arány feljogosíthat bennünket arra, hogy gondolatainkat és észrevételeinket a szakképzés és az anyanyelv-pedagógia, a szaknyelv tekintetében általánosítható értelemben fogalmazzuk meg. Tehetjük ezt annál is inkább, mivel a többi öt területtel határos vagy ott is oktatott szaktárgyak tapasztalatai minden bizonnyal hasonlóak, mint az általunk vizsgált „fóbázisra”, illetve az 1), 2), 3) területre vonatkoztatva.

\section{A szakmai anyanyelv a szakoktatásban, a szakképzésben}

$\mathrm{Az}$ anyanyelvünk oktatásával foglalkozók körében ismert fogalom a magyar mint idegen nyelv (MID) terminus technicus. Ennek a kifejezésnek az analógiájára induljunk ki abból a megállapításból, illetve tételből, hogy a szakmai anyanyelv - a szakképzés, a szakmai tantárgyak során - a tanulók számára sajátos kifejezéssel élve „félidegen nyelvként” jelenik meg, magával hozva a nyelvi idegenszerűség, a nyelvi másság attribútumait. Erről a felmérés némely résztvevője így nyilatkozik: „A tanulók azelött soha nem hallottak ezekröl a tantárgyakról és az ebben használatos szakszavakról sem.” [77] „Azt tapasztalom, hogy az alsóbb évfolyamokon, de még késöbb a felsöbb évfolyamokon is nagyon nehéz a diákoknak a szakmai nyelvezet elsajátítása. Nagyon idegen számukra ez a sajátos nyelvezet, hiszen közvetlen környezetükben nem találkoznak ezekkel a kifejezésekkel, így csak a tanórán hallanak róla." [1] Valójában ez a „félidegen” minősítés, pontosabban az ilyen jelleg adja a szakmai anyanyelv kialakításának és elsajátításának nehézségét. De mik is ezek a „félidegenségre” - azaz a nyelvi és egyben a tartalmi ismeretlenségre - utaló attribútumok? Ennek kapcsán több mindent kell figyelembe venni. Ezek között a szempontok között már úgy navigálunk, hogy a saját alapképzésben és mesterképzésben részt vevő szakoktató, mérnöktanár, közgazdásztanár hallgatóink véleményét, visszajelzéseit, 
konzultációkon kifejtett állásfoglalásait is figyelembe vesszük. Ezek a jellemzők - a szakmát és a szaknyelvet tanulók szempontjából - a következőkben sorolhatók fel:

1. A szakmai anyanyelv legtöbb elemében eddig nem használt vagy nem ismert, új megtanulandó, bevésendő - nyelvi tudásanyag.

2. Megjelenik a szaknyelvi másság összes grammatikai jellemzőjével. Ráadásul a nyelvi kódváltás - az egyik nyelvi rétegből a másik nyelvi rétegbe való átlépés - nehézségeivel minden alkalommal meg kell küzdeni.

3. A szakmai anyanyelv a „zárt rendszer szindróma” vagy a „szabványjelleg” szerint müködik, gyakorlatilag kizárja a külső használókat. Nincs szabad nyelvi mozgás, a szinonima - a szakmai szinten - gyakorlatilag ismeretlen, illetve többnyire kizárt fogalom.

4. Az elsajátítás során mind a rögzítés, mind pedig a reprodukció során előkerülnek a nyelvi másságból eredő nehézségek.

5. A fentiekből fakadóan magas a befogadási ráta értékhatára, többszörösen meg kell dolgoznia a szaknyelvhasználónak a helyes elsajátításért.

6. Az összes előzőekben felsorolt tétel korosztályfüggetlen és szakmafüggetlen. Mind a közoktatás résztvevői (döntően a 14-18 év közötti korosztály), mind pedig a felnőttoktatás résztvevői (a teljes korosztály, igen szórt életkori adatokkal) szembe kerülnek ezekkel a problémákkal.

7. A szakmai tanár oldaláról, pontosabban a szaknyelv átadásának oldaláról nézve meg kell említeni azt a sajátos tényt, hogy a szakmai tanárnak az általa többnyire már ismert „totális szaknyelv” helyett egy ún. „redukált szaknyelvet” kell átadni igazodva a tananyag, a képzési ág szakmai határaihoz és nyelvi szükségleteihez. „Két út nyílik a probléma megoldása felé. Ugyanis bárhogyan nevezzük: ez probléma. Az egyik megoldás az, hogy annyira leegyszerüsitjük a tanitás nyelvét, hogy a gyermek azonnal megértse, de ezzel elindulunk a minimalizálás felé. Vagy felvállaljuk - a nevelési funkciót-, nemcsak a tanitást, és ezzel elkezdjük a szakmai anyanyelvi nevelést!" [103]

8. Végül elengedhetetlen szempontként kell ide sorolni a következő két gondolatot. A szaknyelvismeret, a szaknyelvtudás: munkaeszközként, sőt versenyeszközként is megjelenik a tanulók - azaz a jövő gyakorló szakemberei - számára. Sőt ők, mint a ,jövő szakemberei” több évtizedes távlatokban a szakmai anyanyelv továbbvivői, alakítói, formálói. Így egyértelműen megállapítható a tanár-tanuló kontaktusban a nyelvi tudatosság, az anyanyelvi felelősségtudat kialakításának kérdése is (Kurtán 2006; Dobos 2010).

\section{A nyelvi másság a szaknyelvben, illetve a szaknyelvoktatásban}

A magyar nyelvészettel, az anyanyelvészettel foglalkozók szerint nyelvünk szerkezetét tekintve két ismertebb modell jelenik meg az elemzések szerint. Az egyik a Grétsy-féle ún. „virágmodell”, amely öt virágsziromra emlékeztető körrel, öt nagy nyelvi rétegre, 
csoportra, de inkább halmazra bontja, vagy inkább rajzolja fel nyelvünket (köznyelv, szépirodalmi nyelv, népnyelv, szaknyelv, csoportnyelv); a másik a Balázs-féle ún. „tengelyes modell", amely három tengelyre helyezi a nyelvi rétegeket. A vízszintes tengelyre a nyelvjárásokat (dialektusokat), a függőlegesre a társadalmi vagy funkcionális nyelvi rétegeket (a szociolektusokat), egy átlós tengelyre pedig a regionális köznyelvet mint új fogalmat helyezi fel (Balázs 2001: 10; Grétsy-Kemény: 2005: 411-413). A közös mindkettőben az, hogy a szaknyelv világát elkülönítve és önálló identitásként kezeli. Ez elfogadható állásfoglalás mindkét szerző vagy modellalkotó részéről, mivel ezzel egyértelműen jelzik, hogy a szaknyelv magán hordozza az elkülönítés jegyeit, a nyelvi másságot: azaz a „szaknyelviségnek” megvannak a saját attribútumai, és ezek a nyelvi rendszer - jelen esetben a szaknyelvi rendszer - minden elemén kiütköznek. Ha ezeket az attribútumokat a szaknyelvtanítás és a szaknyelvhasználat szemszögéből és a nyelvi rendszer egésze, illetve szintjei felől kicsit egyszerűsítve és röviden számba kívánjuk venni, akkor a következő, nyelvpedagógiai szempontból is kiemelendő elemeket, illetve jellemzőket sorolhatjuk fel:

1. Hangtan: többnyire az egyéb nyelvi rétegektől - leginkább a köznyelvtől - eltérő vagy idegenszerủ hangkonstrukciók a szakszavakban, a frazeológiai egységekben.

2. Alaktan: sajátos képzőstruktúra, annak mennyiségi eltolódásai bizonyos képzők tekintetében (pl.: -at/-et; -ság/-ség túlsúlya); speciális, ritkán használt képzők megjelenése (pl.: -vány/-vény; -ttyúl-ttyü); bonyolult, többszörös birtokos konstrukciók stb.

3. Lexika: az újszerűség, az ismeretlenség és az idegenszerüség megjelenése mind a magyar, mind pedig az idegen vagy idegenszerü szakaszavak tekintetében; nominális mennyiségi eltolódás a névszók javára; az igék speciális - a köznyelvitől eltérő jelentésü - megjelenése, használata; metaforikus megjelenésủ elemek.

4. Mondattan: bonyolult, alá- és mellérendeltségben élő többszörösen összetett mondatok; rögzített mondatkonstrukciók (pl. meghatározások, kifejtések stb.)

5. Szövegtan: szigorú logisztikai felépítettség, teljes szervezettség; a fenti jellemzőkből összeadódó - a többi nyelvi rétegtől eltérő - szövegarculat; a szabvány szövegminták megjelenése (pl.: jegyzőkönyv, folyamatleírás stb.).

Mindennek a tudatosítása és elfogadtatása a szaknyelvet is átadó szakmai tanár feladata, annál is inkább, mivel az anyanyelvi tanítás, a nyelvtanórák kereteiben keveset foglalkoznak a szakmai anyanyelvünk kérdéseivel. Mondhatjuk azt is, hogy a szaknyelvi attitüd kialakítása szaktanári feladat, mivel bizonyos értelemben nyelvtanári, pontosabban szólva anyanyelvtanári funkcióban is, mint fó forrásnak meg kell jelennie a szakmai tanárnak. A szaknyelvhasználat során gyakorlatilag a nyelvi rétegek vagy regiszterek közötti kódváltás történik, ezt a folyamatot a nyelvhasználó szempontjából nézve és Csépe Valéria szavaival élve „terheléssel járó váltásnak” nevezhetjük, ami a közoktatásban 
részt vevők számára valójában nehéz feladat. Tegyük hozzá ez mind a szakmai tanár, mind pedig a tanuló oldaláról nézve igaz, amint azt a felmérés több részvevője is megállapítja. Ezekből a véleményekből idézünk kettőt: „A tanár és a tanuló átkapcsol egy más minöségü kommunikációra.” [14] „A szakmai kommunikációs zavarok, problémák feloldásához, ahhoz, hogy az üzenet keresztülmenjen a fogadóhoz kell igazodni. Többnyire elöre kell gondolkodni, és azt kell kigondolni, hogy hogyan fogják az üzenetet fogadni." [19]

A fenti öt pontból egyértelműen kiemelhetjük a lexika körét, mivel egyértelműen a szakszókincs a szakmai tudásközösség és a szaknyelvi diskurzusközösség felépítésének az alapja. Ezzel kapcsolatban a szakmai tanárképzésben résztvevő egyik kolléga a felmérés során így nyilatkozik: „A kommunikációs probléma a szaktanár és a diákok között áll fenn, mivel a diákok kevés szaknyelvi ismerettel rendelkeznek az adott témában. Több szaknyelvi kifejezéssel elöször találkoznak a tanórán. A szaktanár azzal szembesül, hogy tanulók több kifejezés kapcsán szövegértési és kiejtési problémákkal rendelkeznek. A szaktanár azzal a feladattal áll szemben, hogy úgy kell átadnia a tananyagot, hogy ezzel párhuzamosan megtörténjen a szakmai terminológia megértése, a kifejezések szakmai kommunikáció szinten való használatának elsajátitása. Az eset az irásbeli és a szóbeli kommunikációt is érinti." [12] Ugyanez a kolléga a lexikai problémák feltárása, elemzése kapcsán felemlíti még a következő és egymásra épülő kulcsszavakat: „a szaknyelvi kifejezések bevezetése, a biztonságérzet megteremtése, a szaknyelvi kifejezések használata, irásbeli és szóbeli használat". [12]

\section{A szakmai kommunikáció építőeleme: a problematikus szókincs}

Ha a tanítás-tanulás folyamatában fellépő és a szakszókinccsel kapcsolatba hozható, nehézségeket okozó problémákat, kritikus elemeket fel kívánjuk tárni, akkor az alábbiakban összegezhető leltárt készíthetjük. Tehetjük ezt azzal a megjegyzéssel, hogy ezek a problémák azért nemcsak a kimondottan a szakmai tantárgyak (pl.: elektrotechnika, mechanika, forgácsolás, talajtan, számvitel, adózásismeret stb.) keretében kerülhetnek elő, hanem az úgymond a „keményebb” közismereti tantárgyak (pl.: biológia, fizika, kémia stb.) esetében is, legfeljebb ritkábban és jóval kisebb töménységben.

1. A lexikai elem elhatárolása más a nyelvi rétegektől jelentés, értelmezés szempontjából.

2. Szófaji tisztázás: pl. szóró, maró (kettős vagy többes szófaji szerepben is megjelenhet: hol fönév, hol melléknév, hol melléknévi igenév).

3. Magyar-magyar (standard szaknyelvi lexika és a szakmai szleng találkozása) és idegen nyelvi megfelelők megjelenése: pl.: tolómérö, tolómérce, subler; sarok, vinkli.

4. Kiejtés (ortoépia), hangkép: szokatlan, ismeretlen, idegenszerü hangkonstrukciók megjelenése; idegen szavak, nevek előfordulása, illetve ezek helyes kiejtése; ejtésvariációk pl.: tümpanon/timpanon.

5. Helyesírás (ortográfia), íráskép: az általános helyesírási elvek és a sajátos szaknyelvi helyesírási szabályok, eszközök, tanácsadó kézikönyvek, szakmai alapállások, esetleg 
variánsok találkozása. Egybeírás, különírás, kötőjelezés (nagy- és kiskötőjel használata), nagybetü-kisbetű használat stb. Ez a problémakör messze túlmutat a csak tanulói problémákon, hiszen magát a szakma egészét is érinti. Egy 2002-ben tartott szaknyelvi és egyben szakmai helyesírási tanácskozás - ma is érvényes - megállapításaiból idézzük fel az összegzés néhány pontját: „- nincs kellően szabályozva az egyes szaknyelvek helyesírása... [...] - a helytelen alakok hamar elterjednek és megszilárdulnak; - végül egy több helyen felmerült kérdés: jogunk van-e az általános helyesírási szabályoktól eltérő, az adott szakma nyelvében használt egyedi írásmódra, ha szakmai közmegegyezés alakult ki?” (Zimányi 2003: 13)

6. Verbális, nonverbális és részben nonverbális elemek szerves kapcsolódása: a lexikai és a nem-lexikai ismeretlen elemek együttléte, gyakori találkozása, pl. T-vas, U-profil, lambda-szonda, khi-próba; különböző rajzjelek, ábrák, színjelzések verbális átváltása.

7. Terminológia: egy- és főleg a többeleműség megjelenése. Ezzel kapcsolatban joggal idézhetjük a problémaelemzo” észrevételét, mely szerint: „Az utóbbi évtizedek jellemzője, hogy megnőtt a többszörös szóösszetételek és a bonyolult fogalmak száma” (Zimányi 2017: 1128). Ez az állítás különösen igaz a szaknyelvre, kiegészítésül lásd még konkrét példákat bemutatva Zimányi Árpád Proxy címü cikkét (2018: 13).

8. Szabványjelleg: a standard lexikai formák kialakítása, megerősítése szemben a szakmai szleng világával és/vagy annak bevonásával.

9. Metaforahasználat, képszerűség. A szaknyelv esztétikumának vizsgálata kapcsán Zimányi Árpád egyik cikkének a következő címet adja: „Lehet-e "szép“ a szaknyelv?”, majd így válaszol: „A címbeli kérdésre nem adhatunk érdemleges választ. Ha viszont a szaknyelv képszerüségét firtatjuk, akkor már hitelesebben nyilatkozhatunk: a szaknyelv képszerűsége valóban lehet figyelemre méltó, érdekes vagy akár szép is. A szaknyelvi szövegekben sokszor találkozunk olyan metaforákkal, amelyek merőben különböznek a köznyelvben megszokott fordulatoktól” (2016: 1448).

10. Szócsaládba, fogalomcsaládba, ábrába, nonverbális kapcsolatrendszerbe való beillesztés.

A felsoroláshoz két megjegyzést füzhetünk: egyrészt a felsoroltak szoros összefüggésben és átfedésben vannak a szaknyelv másságáról szóló grammatikai elemekkel; másrészt ezek az elemek vagy jelenségek a szakszókincsi elem megjelenésekor nem külön-külön jelennek meg, hanem többnyire egymást átfedve, mintegy halmazati megjelenésük van. Ezzel összetett, mondhatni komplex nyelvpedagógiai problémaként mutatkoznak meg mind az adó, a tanár, mind pedig a vevő, a tanuló oldaláról nézve. A következő alfejezetben ezekre a jelenségekre hozok példákat: először a műszaki, majd a közgazdasági területről. A példaanyagot a mesterképzésben részt vevő szakmai tanárok „közoktatási gyűjteményéből, példatárából” merítettem az 2018/19-es tanév első félévének során készült felmérésből, ahol úgymond a saját gyűjteményükből és tanulói oldalról nehezen befogadható példákat mint problémás eseteket sorolták fel. A példák különböző 
szakterületek tananyagából, tantárgyaiból származnak. Az alábbi bemutatott, először a műszaki majd a közgazdasági szaktárgyak világából kiemelt példaanyagot a fenti „problémafelsorolást” és a szakmai tanároknak a példához füzött megjegyzéseit vagy értékelését figyelembe véve kommentáljuk.

\subsection{Szemléltető példatár: műszaki terület}

Föte: bányaművelési szakszó, a bányajárat felső fala.

Eketalp-betegség: ekevasmélység hibás beállításából származó talajhiba; mindkét példa a „félidegenséget” példázza, tartalma, jelentése, megjelenése ismeretlen, magyar szó, szóösszetétel.

Franciakulcs, körmöskulcs, nyomatékkulcs, villáskulcs: szakmailag és egyben jelentésileg teljesen elkülöníthető szerszámok, a tanulók gyakran és helytelenül szinonimahalmazként kezelik ezeket; megjelenik az egyedi értelmezés, azonosítás és a szócsaládba illesztés helyességének-helytelenségének problémája; vagy a szakszerűtlen azonosításként az előtag nélküli, pusztán a kulcs szó megjelenése.

Boltiv, boltöv, dongaboltozat, kontyolás, torokgerenda, fecskefarkú rálapolás: építészeti, épületszerkezeti elnevezések, jelentésbeli elkülönítési problémák, a metaforikus példák értelmezési gondjai jelennek meg.

Árutonna-kilométer: a többelemüség a különböző mértékegységek megjelenések értelmezési és szimbolikus átviteli problémája.

Vierendel-tartó, Whitworth-menet, Karnaugh-tábla: kiejtési, helyesírási, értelmezési, rögzítési problémák együttes megjelenése; sorrendben egy épületszerkezeti (tartószerkezet-típus megnevezése), egy gépészeti (a csavarmenetek egyfajta típusa) és egy matematikai-statisztikai kifejezés; ráadásul a szakirodalom írásmódjában és a szakmai gyakorlat kiejtésében sem egyértelműen és egységesen használja a kifejezéseket. Az utolsó példánkat - a Karnaugh-táblát -, amit több szakterület is használ, bonyolíthatja egy a tankönyvekben vagy a segédanyagokban előforduló, bővítő szándékú lábjegyzet, miszerint: "A Karnaugh-tábla vagy más néven Veitch-diagram a Boole-féle algebrai kifejezések egyszerüsitését teszi lehetövé."

Folyamatosan müködö anyagmozgató rendszer: példa a totális szabványjellegre és a megjegyezhetetlen többeleműségre, ahol a szórendnek felcserélhetetlen és kötelező szerepe van.

\section{2. Szemléltető példatár: közgazdasági terület}

Tanúsitás, tanuisitvány: jelentéstani elkülönítés hibája, a finomhangolás hiánya, a közelség zavara, a képzoértelmezés hiánya, a folyamatra, illetve az eredményre (a dokumentumra) vonatkozó fogalom keverése.

Közgazdasági mátrix, speciális mátrix, mátrixsorozat, mátrixblokk, hipermátrix, inverzmátrix (inverz mátrix, *inverz-mátrix), eredménymátrix (*eredmény-mátrix), kétirányú mátrix, kommulált mátrix: hasonló viselkedésủ példasor, mint a műszaki példatárban bemutatott kulcs szósor, de az elemek sokkal nagyobb jelentéstani és funkcionális 
különbséggel rendelkeznek. A közgazdasági mátrix mint gyűjtőfogalom alá tarozó fogalomsor rögzítése több szempontból kritikus: kiejtés, helyesírás, jelentéskülönbség, osztályba sorolás.

Keresztár-rugalmasság: árak, cégajánlatok, árvita találkozása; a „félidegenség” megjelenése, az egymáshoz való viszonyban értelmezhetetlen szavak, nehezen rögzíthető terminológiai egység.

Eszközár-buborék: az előző példához hasonló eset, metaforikus és analógiás megjelenéssel; gyakorlatilag egy új szó, egy neologizmus bevezetése.

Institucializmus: csak definitív módon, körülírással értelmezhető: a gazdasági jelenségeket egyoldalúan szubjektív akarati tényezőkkel magyarázó gazdaságtani irányzat; a teljes idegenszerűség példája, kiejtési, helyesírási, értelmezési kérdések megjelenése; ráadásul bezavarhat, hogy a közgazdaságin túl politikai, filozófiai, szociológiai - egymástól különböző - értelmezése is van.

Aszimmetrikus interdependencia: gazdasági egyenlőtlenség fogalmának bevezetése; szabványjelleg, idegenszerűség, kiejtés, helyesírás, a terminológiai elem jelentésének, értelmezési problémájának együttes megjelenése.

Jogi személyiséggel rendelkezö gazdasági társaság: a totális szabványjelleg és a megjegyezhetetlen többeleműség megjelenése, ahol a szórendnek felcserélhetetlen és kötelező szerepe van.

$M N B, P S Z A F F$, 4P: helyesírási és kiejtési problémák megjelenése, szakmai kifejtés során a teljes feloldás problémája, továbbá a toldalékolás kérdései a betűszavak és a mozaikszavak esetében. Az utolsó példában (4P) az idegen nyelvü (angol: product, price, place, promotion) feloldás, írásmód, kiejtés, továbbá a precíz és állandósult magyar megfeleltetés hánya, illetve a két nyelvi forma, gondolatsor helyes párosításának kérdése. A 4P elemeinek, fogalmának rögzítését további két tényező is befolyásolhatja: a marketing mix, mint alapfogalom vagy előzetes fogalom tisztázása, illetve a tovább-bővített fogalomnak, a $7 P$-nek (az előző négy plusz a következő három fogalom vagy kulcsszó: people, physical evidence, process) a bevezetése.

A szemléltető példatárhoz hozzáfüzhetjük, hogy több esetben „bizonytalansági tényezőkre” vagy használatbeli „ingadozásra” is utaltunk. Ennek okát a gyors lexikai fejlődésben, a szakkönyvek, a tankönyvek, segédanyagok vagy éppen az iskolák eltérő szóhasználati rendjében, de leginkább a standardkialakítás műhelymunkájának hiányában - azaz a szakmai nyelvművelés gyengeségeiben - kereshetjük. Úgy tűnik, hogy Szily Kálmán mintegy másfél évszázaddal korábbi megállapítása - a „természettudományos műnyelvről”, azaz a szaknyelvek világáról - bizonyos részleteiben még mindig aktuális. 1879-ben így fogalmaz: „Ez a mi szegény természettudományi műnyelvünk csak nem bír megállapodásra verődni. Tájékozatlanság, ingadozás, személyes önkény tűnik elénk minden lépten-nyomon. Az egyik iskola egészen más műnyelven beszél, mint a másik. Sőt mi több, ugyanazon az egy iskolán belül az egyik tanár emilyen, a másik meg amolyan műkifejezéseket ver egyazon tanuló fejébe" (Szily 1879: 329). 


\section{Szakszókincs és nyelvpedagógia}

\subsection{Jó gyakorlatok, pedagógiai megoldási javaslatok}

A szakmai tanárképzésben résztvevő tanárkollégák - szóbeli nyilatkozataikban, felméréseinkben - egyaránt és egyértelműen úgy nyilatkoztak, hogy a szakmai anyanyelv átadása során a szaklexika pontos megismerése, elsajátítása kiemelt feladat a munkájukban. Ezt bizonyítja az is, hogy a tanári módszerek és az ún. jó gyakorlatok között a legtöbb ötletet, javaslatot a szaklexika kialakításával kapcsolatosan sorolták fel: részben nehézségként, részben sikeres megoldásként, módszertani fogásként. Ezt a témát azért is érzik úgymond neuralgikusnak, mert a szakmai tankönyvek, jegyzetek, segédanyagok - ritka kivétellel - nem tartalmaznak sem fejezetzáró egységként, sem pedig záró egységként lexikai összefoglalót, glosszáriumot vagy más egyéb a lexikai feldolgozást segítő, megerősítő vagy ellenőrző részanyagot. Ehhez csak két - a tankönyvek ilyen értelmü méltatásához kapcsolható - felmérésbeli megjegyzést idézhetünk: „A kulcsszavak nem kerülnek kiemelésre, nincs magyarázatuk.” [7] „Vannak szakszavak, melyek elöször helytelenül szerepelnek, majd a késöbbiekben helyesen vannak leirva. Ebböl a szempontból összezavarhatja a tanulókat (pl. szórás szélesség, szórásszélesség; szóró gép, szórógép." [8]

Éppen ezért úgy tűnik, hogy önerős ellátásra vannak berendezkedve a kollégák. A jó gyakorlatba sorolható fogások eltérő mélységủek és eltérően hatékonyak, de a cél mindegyik megoldás esetében az, hogy a szaklexika - tartós elemként és mondat- vagy szövegépités alapegységeként - minél inkább beépüljön a tanulók tudatába. A jó gyakorlatok sorában a következő megoldásokat, fogásokat javasolták, többnyire azzal a megjegyzéssel, hogy a motiváció, az aktivitás, az élményjelleg és a siker erősen növelhető az „elektronikus kütyük” és a „digitális írástudás” minél szélesebb körű bevonásával. Ez a megoldás a tanár szempontjából is újfajta munkát és megközelítést igényel, de előnyei között tarható számon a tartós tárolás, a variálás, a módosítás és a bővítés lehetősége, a játékos megoldás, a gyorsaság. Ezzel kapcsolatban nehézséget pedig a begyűjtés, az ellenőrzés és visszajelzés okozhatnak.

1. Tanulói szótárkészítés: ábécérendbe szedett kézírásos szakszótár, esetleg elektronikus változat készítése.

2. Tanulói glosszáriumkészítés: a fenti szótár mintájára, de annak meghatározásokkal, körülírásokkal, szókapcsolatokkal, szócsaláddal bővített változata, a lexikai elemmel kapcsolatos egyéb felmerülő problémák rögzítése.

3. Szódolgozat: ellenőrző feladat, speciális feladatlap.

4. A gamifikáció, azaz részben már a „játékosság” körébe tartozóak az alábbi feladattípusok:

5. Szóteszt több variációban: választós; definitív-kifejtő jellegű; ábrás-figuratív összekötő jellegű; igaz-hamis állítás.

6. Szókártya: szóanyag azonosítása képanyag vagy ábraanyag segítségével. 
7. Esettanulmány: megadott és tematikus szakszavak, illetve szituáció alapján (irányított írásbeli gyakorlat).

8. Szerepjáték: megadott és tematikus szakszavak, illetve szituáció alapján (irányított szóbeli gyakorlat).

9. Szöveggyakorlatok írásban, szóban: a kulcsszavak meglétének, helyességének kiemelt és külön értékelése.

10. Szókincs-azonosítási vagy párosítási gyakorlat kép, tabló, okostábla, internetkép alapján.

11. Szókincs-azonosítás vagy párosítási gyakorlat modell, valóságos tárgy, valóságos helyszín és munkaforma (műhely, mintabolt, építkezési terület, szerelési feladat stb.) alapján.

12. A „szakmai kétnyelvűség” a standard szakszókincs és a műhelyszleng, a szakmai szleng azonosítási gyakorlata.

\subsection{Pedagógiai, nyelvpedagógiai problémák}

Keresni kell arra is a választ, hogy a szakmai nyelvhasználatban felgyült lexikai hibák és hiányosságok milyen, a tanulást, a szakmai anyag elsajátítását zavaró vagy gátló, a szövegértést nehezítő következményekkel járnak. Erre a következő önállóan megjelenő vagy többnyire inkább egymással összefüggő, mennyiségi és minőségi szempontból eltérő súlyú, láncreakciót okozó esetek, tételek az alábbiakban felsoroltak szerint írhatók le, illetve minősíthetők. Ezeket részben a szakmai tanárok által leírt anyagok alapján, részben a konzultációk során folyt szakmai megbeszélések és vita alapján mintegy összegző és konszenzusos véleményt fogadhatjuk el. A felsorolás előtt meg kell említeni egy vissza-visszatérő szót vagy jelzős szókapcsolatot, amely minősítést vagy véleményt mond a szaknyelv tanításával-tanulásával kapcsolatban, miszerint a véleményezők többsége „kihivásnak”, „nagy kihivásnak”, „veszélyes kihivásnak”, „bizonytalansággal teli kihivásnak" itélte meg a szaknyelvoktatást és a szaknyelv-elsajátítást. Úgy tűnik, hogy ez a tapasztalatokból fakadó minősítés nemcsak a nyelvi, hanem a vele összefüggő tágabb pedagógiai problémákra is kitekint.

Olvasási, írási zavarok: a pontatlan, szakszerütlen elsajátításból fakadnak. Kiejtési nehézségek: a különös hangkonstrukciók nem rögzítése, nevek kiejtésének megőrzése. Szövegértési zavarok. Tanulási nehézségek, zavarok. Reprodukciós elégtelenségek. A lexikai hiány fellépése kommunikációs fékként: a lexikai elemek - a szövegépítő elemek - hiánya vagy hibás megléte gátolja vagy lehetetlenné teszi a szakmai kommunikációt. Beszédzavarok, fogalmazási zavarok. Pszichológiai problémák. Viselkedési problémák.

A fentiekben felsorolt beszédzavarok, tanulási nehézségek, pszichológiai problémák, viselkedési problémák - elszakadva az általunk tárgyalt eredeti októl, a szaknyelvi problémáktól - később exponálódhatnak más tantárgyakra, illetve az egész kommunikációs viselkedésre is. Megjegyezhetjük, hogy ez az exponálódási folyamat „visszafele ható folyamatként" is igaz, akkor, ha a tanuló már eleve magával hozza - a szakmai, szaknyelvi 
tanulmányaiba - ezeket a problémákat, mint a rá jellemző vagy éppen általános tanulási nehézségeket. A szaknyelvi ismeretekkel kapcsolatban idézzünk ide egy olyan véleményt, amelyik „messzire ható nyelvpedagógiai távlatokban” gondolkodik: „Ha rosszul rögzülnek bennük a szaknyelvi kifejezések, akkor az ismeretek hiánya késöbbi munkavállalásuk során problémát fog okozni. A szaknyelv ismeret nélkül az adott szakmában nincsen esélye versenyhelyzetekben. [...] Ezzel a munkavállaló saját dolgát neheziti, szakmai megbecsülése a kollégák között nem lesz, egy idö után nem tud érvényesülni a piacon, emiatt pedig elhagyja a szakmát." [64]

\section{Nyelvészeti futurológia, avagy üzenet a múltból a jövőnek}

A tanulmányt bevezető mottóban Ferdinand de Saussure-nek a nyelvhasználatra vonatkozó egyik mondatát idéztük. Most idézzük ide - egy Saussure-kortárs, magyar szerző - Bakonyi Hugó pszichológus, nyelvész, nyelvpedagógus meglepően modern és jövőbe mutató, a nyelvészetre és a nyelvre vonatkozó gondolatait: „Nem valószínűtlen, sem nem túlzó feltevés, hogy valamikor kellö nyelvi, főképp pedig jelentéstani előtanulmányok nélkül semmiféle szaktudomány sem művelhető, és hogy minden tudomány alapvető tudománya lesz a nyelvészet. [...] A modern tudomány többi kutatási eszközeihez hasonlóan végre mint legegyetemesebben alkalmazott ily eszköznek a nyelvnek is jóval szabatosabb és lehetőleg minden kételyt kizáró kifejezési képességre kell emelkedni” (Bakonyi 1918: 144). Igazából Bakonyi gondolatában a „pedagógiai lingvisztika” vagy a „nyelvpedagógia” alapgondolata, pontosabban annak funkcionális szerepe és haszna fogalmazódik meg.

Egy valóban esszéjelleggel írott tanári dolgozatban meglepő, de igaz és az egész témát meghatározó nyelvészeti állítással találkoztam: „Grice maximái az iskolai kommunikáció világában is értelmezhetök: mennyiség (csak a lényeges információkat nyújtsuk), minöség (letisztult, megbizható információk), relevancia (lényeges, megértést szolgáló információk), mód (tömör, koherens, zaj nélküli átadás)." [72] Az elemző a maximák mélyebb kibontására is vállalkozott, és úgy értelmezi, hogy a szakmai kommunikációban és a szaknyelvi tudás kialakításában mindennek különösen jelentős szerepe van (Grice 1997; Herbszt 2008).

Mindezek alapján megerősítjük azt a korábbi állításunkat, hogy a szakmai tanár kettős feladatkörben és kettős felelősséggel kénytelen dolgozni. A szaktantárgyi tudástartalom átadása mellett nyelvtanárként - pontosabban fogalmazva szakmai anyanyelvi tanárként - is szerepet kell vállalnia, mert csak így van esélye arra, hogy a szakmai tudásközösség kialakítása során a szakmai beszélőközösséget is sikeresen kialakítsa a rá bízott tanulókban, hallgatókban. A „kettős felelősségtudat” kialakításának a szakmai tanárképző központok munkájában is meg kell jelenni. Ha tágabbra kívánjuk húzni a kört, akkor azzal zárhatjuk a témát, hogy a tanárképzés minden szintjén és formájában - a közismereti és a szakmai tanárképzésben egyaránt - ott kell lenni a tantervekben egy szaknyelvi és egyben nyelvpedagógiai kurzusnak. 


\section{Irodalom}

Bakonyi Hugó 1918. A nyelvek és az egyedek szókincse. Uránia 5: 134-144.

Balázs Géza 2001. Magyar nyelvhelyességi lexikon. Budapest: Corvina Kiadó.

Berki Éva 2015a. A szakmai tanárképzés szakterületi alapismeretei. Budapest: BME

Tanárképző Központ, Digitális Tankönyvtár.

Berki Éva 2015b. Képzésfejlesztés a szakmai tanárképzésben. Opus et Educatio 2/3: 78-87.

https://doi.org/10.3311/ope.56

Dobos Csilla (szerk.) 2010. Szakmai kommunikáció. Segédkönyvek a nyelvészet tanulmányozásához 110. Miskolc, Budapest: Miskolci Egyetem, Tinta Könyvkiadó.

Dengl János 1937. Magyar nyelvhelyesség és stílus. Budapest: Grill Károly Könyvkiadóvállalata.

Grétsy László 2002. Szily Kálmán mint nyelvész. Természet Világa 11/12: 550-551.

Grétsy László - Kemény Gábor (szerk.) 2005. Nyelvmüvelő kéziszótár. Budapest: Tinta Könyvkiadó.

Grice, Herbert Paul 1997. A társalgás logikája. In: Pléh Csaba - Terestyén Tamás Síklaki István (szerk.): Nyelv - kommunikáció - cselekvés. Budapest: Osiris Kiadó. 213-227.

Herbszt Mária 2008. Grice társalgási maximáinak érvényesülése a tantermi interakcióban. Anyanyelv-pedagógia 1/3-4. http://www.anyanyelv-pedagogia.hu/cikkek.php?id=88

Hrubos Ildikó - Pfister Éva (szerk.) 2011. Szakmai tanárképzés: múlt - jelen - jövö.

Budapest: Budapesti Corvinus Egyetem, Aula Kiadó.

Kurtán Zsuzsa 2006. Szaknyelv. In: Magyar nyelv. Budapest: Akadémia Kiadó. 932-957.

Lőrincz Éva Anna - Sturcz Zoltán 2013. Prezentáció. Tankönyv / Digitális tananyag. Budapest: Typotex Kiadó.

Sturcz Zoltán 2004. Egy tantárgytörténeti epizód a magyar nyelvhelyesség és stílus oktatásából. Hungarológiai Évkönyv V/1: 190-197.

Sturcz Zoltán 2006. Szakmai kommunikáció, szakmai képzés, nyelvpedagógia. In: Benedek András (szerk.): Szakképzés-pedagógia. Budapest: Typotex Kiadó. 157-190.

Sturcz Zoltán 2009. Kell-e a szakmai nyelvművelés a felsőoktatásban? Nyelvinfo 17/1: $3-13$.

Sturcz Zoltán 2010. Megállapítások és felvetések a műszaki tudományok nyelvéről. In: Dobos Csilla (szerk.): Szakmai kommunikáció. Segédkönyvek a nyelvészet tanulmányozásához 110. Miskolc, Budapest: Miskolci Egyetem - Tinta Könyvkiadó. 421-446.

Sturcz Zoltán 2015. A szakmai nyelvmüvelés alapjai. (Szemléletformáló nyelvpedagógiai, módszertani segédanyag a szakképzésben részt vevő oktatók, előadók számára.) Elektronikus tananyag. Budapest: BME Tanárképző Központ.

Szily Kálmán 1879. A természettudományos műnyelvről a magyar irodalomban. Természettudományi Közlöny 11/121: 329-345. 
Zimányi Árpád 2003. A szakmai helyesírás újabb feladataiból. Magyar Nyelvör 127/1: $12-23$.

Zimányi Árpád 2016. Lehet-e „szép” a szaknyelv? Élet és Tudomány LXXVI/46: 1448. Zimányi Árpád 2017. Szakszavaink helyesírásáról. Élet és Tudomány LXXII/36: 1128. Zimányi Árpád 2018. Proxy. Édes Anyanyelvünk 40/2: 13.

\section{Források}

Hallgatói felmérés és véleménykérés: Időpont: 2018/19. 1. félév. Helyszín: Budapesti Műszaki és Gazdaságtudományi Egyetem Tanárképző Központ. Korpusz: 105 fő közgazdásztanár, mérnöktanár hallgató esszéjellegű dolgozata. Felmérési, véleményezési témakör címe: Szakmai kommunikációs, szakmai anyanyelvi, pedagógiai problémák a szakmai tantárgyak oktatása során.

2011. évi CCIV. törvény a nemzeti felsőoktatásról

8/2013. (I. 30) EMMI-rendelet a tanári felkészítés közös követelményeiről és az egyes tanári szakok képzési és kimeneti követelményeiről

18/2016. (VIII. 5.) EMMI-rendelet a felsőoktatási szakképzések, az alap- és mesterképzések képzési és kimeneti követelményeiről

Statisztikai Tükör: Központi Statisztikai Hivatal, Oktatási Adatok 2017/2018. 1-5. [PDF-formátum] 